\title{
Effect of microbial composition on thermophilic acid fermentation
}

\section{$\operatorname{AUTHOR}(\mathrm{S}):$}

Hidaka, T.; Asahira, T.; Koshikawa, H.; Cheon, J.; Park, Y.; Tsuno, $\mathrm{H}$.

\section{CITATION:}

Hidaka, T. ... [et al]. Effect of microbial composition on thermophilic acid fermentation. Enzyme and Microbial Technology 2010, 47(4): 127-133

\section{ISSUE DATE:}

2010-09-06

URL:

http://hdl.handle.net/2433/128756

\section{RIGHT:}

(c) 2010 Elsevier Inc:; この論文は出版社版でありません。引用の際には 出版社版をご確認ご利用ください。; This is not the published version. Please cite only the published version. 


\section{Effect of microbial composition on thermophilic acid fermentation}

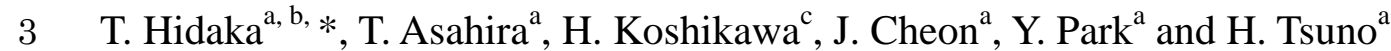

5 a Department of Urban and Environmental Engineering, Kyoto University, Kyoto-Daigaku-

6 Katsura, Nishikyo-ku, Kyoto 615-8540, Japan

$7 \quad{ }^{\mathrm{b}}$ Department of Civil and Environmental Engineering, University of Cincinnati, Cincinnati, Ohio

8 45221-0071, USA

$9 \quad{ }^{c}$ Department of Environmental Solution Technology, Ryukoku University, 1-5, Yokotani, Setaoe-

10 Cho, Otsu, Shiga 520-2194, Japan

11

$12 *$ Corresponding author.

13 Tel/Fax: +81-75-383-3350/3351;

14 E-mail: hidaka@water.env.kyoto-u.ac.jp (T. Hidaka) 


\section{Introduction}

Resource recycling and energy-saving systems for processing organic solid waste in urban areas and recovery process for the treatment of organic solid waste with a high water content such as kitchen garbage. Anaerobic digestion is considered to take place in two steps: an acid fermentation phase and a methane fermentation phase. A single-phase system, in which these two steps proceed simultaneously in one reactor, is commonly used because of simplicity in configuration and operation. However, a two-phase system, which consists of separate acid and methane fermentation reactors, has several advantages over conventional single-phase systems [1-3]. Acid fermentation produces many kinds of organic acids such as lactate, butyrate and acetate, and hydrogen gas. Bio-hydrogen production from organic wastes was widely developed and optimal operational conditions such as $\mathrm{pH}$, temperature, substrate and product concentrations, hydraulic retention time (HRT) or solids retention time (SRT) were proposed [4]. Recently, thermophilic condition has been focused on for hydrogen fermentation due to thermodynamic advantage at higher temperature [5]. Akutsu et al. [6] reported that hydrogen production in thermophilic continuous hydrogen fermentation of starch at $\mathrm{pH} 4.9-5.4$ was successful with four different seed sludge, the most predominant microbe was Thermoanaerobacterium, but hydrogen production was low and some lactate was produced with one seed sludge due to unknown reason. 
1 Shin et al. [7] reported that Thermoanaerobacterium and Desulfotomaculum were detected in

2 thermophilic hydrogen fermentation at $\mathrm{pH} 5.5$ from food waste but not Bacillus coagulans.

3 Ueno et al. [8] reported that Bacillus spp. were observed under high OLR conditions in

4 thermophilic hydrogen fermentation using glucose. Ueno et al. [9] reported that no significant

5 lactate was produced at $\mathrm{pH} 5-8$ in thermophilic hydrogen fermentation from organic waste, $B$.

6 coagulans was detected at $\mathrm{pH} 6$, and its ratio was lower than Clostridium spp. and

7 Thermoanaerobacterium spp. While a simple thermophilic L-lactate fermentation of organic

8 wastes under nonsterile conditions using B. coagulans has been developed [10-14]. Akao et al.

9 [14] reported that operational conditions of $\mathrm{pH} 5.5$ and $55^{\circ} \mathrm{C}$ were suitable for L-lactate

10 fermentation of kitchen garbage by indigenous $B$. coagulans, and other bacteria were eliminated

11 under these culture conditions. Typical formulas of hydrogen fermentation from glucose are as

12 follows:

$$
\text { Glucose }+2 \mathrm{H}_{2} \mathrm{O} \rightarrow 2 \text { acetate }+2 \mathrm{CO}_{2}+4 \mathrm{H}_{2}
$$

$$
\text { Glucose } \rightarrow \text { butyrate }+2 \mathrm{CO}_{2}+2 \mathrm{H}_{2}
$$

15 Yields of hydrogen by butyrate type fermentation carried out by some Clostridia are lower than

16 that of acetate fermentation. Failure in hydrogen fermentation is also widely reported, and one

17 of the typical reasons is lactate production.

$$
\text { Glucose } \rightarrow 2 \text { lactate }
$$


1 Hydrogen fermentation is a kind of acid fermentation, and proposed operational parameters for

2 hydrogen fermentation and lactate fermentation are similar. However, key parameters to

3 determine microbial composition and product differences in acid fermentation are still uncertain.

4 Microbial concentrations associated with acid fermentation have been estimated by

5 measurements of Suspended Solids (SS), COD, optical density, protein, and total DNA mass.

6 However, these indices are not appropriate for understanding microbial composition and

7 concentrations in fermentation reactors using complex substrates containing organic particulate

8 materials such as kitchen garbage. Microbial composition can be measured using molecular

9 biology techniques such as random cloning method [15]. Recently, quantification of microbes

10 can be done using quantitative real-time polymerase chain reaction (PCR) with specific primer

11 sets for quantifying specific microbes. The applicability of real-time PCR quantification to

12 evaluate methanogenic behavior has been reported [16, 17]. Li et al. [18] proved the

13 applicability of TaqMan gene probe for real-time monitoring of acidophilic hydrogen-producing

14 bacteria. Wang et al. [19, 20] reported relationship among hydrogen production, growth

15 parameters, and quantitative molecular biological tools. However, they were based on only

16 batch experiments with operational periods of around $120 \mathrm{~h}$. Combined discussion of microbial

17 composition and products is useful in evaluating continuously-operated acid fermentation

18 reactors. 

and products in an acid fermentation process using kitchen garbage. For this purpose, a

3 continuous thermophilic fermentation experiment was performed using kitchen garbage. HRT

4 and SRT were separately controlled to evaluate their effects on hydrogen and acid fermentation.

5 Microbial composition shift was analyzed using random cloning method, and quantification of $B$.

6 coagulans, which was identified as a key microbe to evaluate the reactor performance, was

7 performed using real-time PCR.

\section{Materials and methods}

\subsection{Reactor and operation}

11 The continuous experiment was performed in a reactor of a $4.5 \mathrm{~L}$ working volume in which

12 anaerobic conditions and complete mixing were maintained. Operational conditions are

13 summarized in Table 1 . Culture temperature was set at $55^{\circ} \mathrm{C}$ using a hot water bath and $\mathrm{pH}$ was

14 automatically controlled at 6 by the addition of $10 \mathrm{~N} \mathrm{NaOH}$ (Nisshinrika, NPH-660). Artificial

15 kitchen garbage was prepared by mixing 14 types of foods, based on a survey conducted in Japan

16 [21]. The kitchen garbage comprised 10\% cabbage, $10 \%$ potato, $10 \%$ carrot, $10 \%$ radish, $10 \%$

17 Chinese cabbage, $2.5 \%$ apple, $7.5 \%$ orange peel, $10 \%$ banana peel, $10 \%$ boiled rice, $2.5 \%$ bread,

$187.5 \%$ noodles, $2.5 \%$ boiled eggs, $2.5 \%$ meat, and $5 \%$ fish. The characteristics of this raw 
1 garbage are summarized in Table 2. Materials were mixed, milled into a slurry and stored in a

2 freezer until use. This garbage was diluted two-fold and used for the acid fermentation

3 experiment. The operation was continued in a fill-and-draw style once a day, and samples were

4 taken just before feeding. Seed sludge was originally obtained from a thermophilic digester

5 plant of kitchen garbage, and then it was cultured for about 5 years using similar kitchen garbage

6 in our laboratory.

$7 \quad 2.2$ Chemical analysis

8 Lactate and other organic acids were analyzed using High Performance Liquid Chromatography

9 (HPLC) (Organic acids analysis system, column; Shima-pack SCR-102H, Shimadzu, Kyoto,

10 Japan). Carbohydrate concentration, expressed using glucose concentration as standard, was

11 determined using a phenol-sulfate method [22]. Protein concentration was determined using

12 Lowry method [23]. Carbon dioxide, hydrogen and methane were analyzed using CG-14B

13 (Shimadzu). Total solids (TS), SS, volatile solids (VS), total and soluble COD (TCOD and

14 SCOD, respectively) were analyzed according to the Standard Method [24]. Total nitrogen was

15 analyzed using Auto Analyzer II (BRAN+LUEBBE, Norderstedt, Germany) after digestion by

16 peroxydisulfuric acid. Dissolved samples were prepared by filtration through a cellulose acetate

17 filter $($ pore size $=0.45 \mu \mathrm{m})$.

18

\subsection{Molecular biological analysis}


1 The microbial community was analyzed using random cloning method [15]. 16S rRNA gene was extracted using a DNeasy Tissue Kit (Qiagen, Hilden, Germany). A primer set of

3 UNIV519F (5'-cagcmgccgcggtaatwc-3') and UNIV1406R (5'-acgggcggtgtgtrc-3') [25] for most

4 bacteria and archaea was used to amplify approximately 900 and 700-bp fragments, respectively.

5 Polymerase chain reaction (PCR) conditions (PTC-200 DNA Engine, MJ research, Watertown,

6 MA, USA) were at $94^{\circ} \mathrm{C}$ for $5 \mathrm{~min}$, followed by 30 cycles of at $94^{\circ} \mathrm{C}$ for $1 \mathrm{~min}$, at $68^{\circ} \mathrm{C}$ for $1 \mathrm{~min}$

7 and at $72^{\circ} \mathrm{C}$ for $1 \mathrm{~min}$. The final extension step was at $72^{\circ} \mathrm{C}$ for $5 \mathrm{~min}$. The amplified $16 \mathrm{~S}$ rRNA

8 gene was separated by 2\% (w/v) agarose gel (SeaKem GTG Agarose, Cambrex, Rockland, ME,

9 USA) electrophoresis run at $135 \mathrm{~V}$ for $45 \mathrm{~min}$. $16 \mathrm{~S}$ rRNA gene products were purified with

10 QIAquick Gel Extraction Kit (Qiagen). The purified products were ligated into pCR4-TOPO

11 vector (Invitrogen, Carlsbad, CA, USA) and then transformed into Escherichia coli TOP10

12 competent cells. Colonies were screened on LB-based agar plates with Kanamycin, X-gal, and

13 IPTG. Cells from randomly selected white colonies were assayed on an LB medium at $37^{\circ} \mathrm{C}$ for 1

14 hour. The plasmids were extracted using QIAprep Spin Miniprep kit (Qiagen) and entreated

15 sequencing of 16S rRNA gene at the TaKaRa Bio Dragon Genomics Center (Yokkaichi, Japan).

16 Obtained sequence data were compared with similar sequences in National Center for

17 Biotechnology Information data using the BLAST program [26]. All clones having a sequence

18 similarity of more than $97 \%$ with each other were grouped into an operational taxonomic unit 
$1 \quad(\mathrm{OTU})$

For real-time PCR reactions, LightCycler 1.2 (Roche, Mannheim, Germany) was used to

3 quantify the target microbes [27]. A primer pair of BACO186F (5'-gcatggaggaaaaaggaa-3') and

4 BACO447R (5'-cccggcaacagagtttta-3') for quantification of $B$. coagulans was developed

5 (Asahira T. Quantification of identified microbes in thermophilic methane fermentation reactors

6 based on 16S rDNA. Master thesis, Kyoto University 2006). The primer set of UNIV519F and

$7 \quad$ UNIV1406R [25] was used for total bacterial measurement. All reactions used $20 \mu \mathrm{L}$ reaction

8 capillary tubes with the LightCycler FastStart DNA MasterPlus SYBR Green I (Roche). Each

9 capillary tube was separately loaded with $1 \mu \mathrm{L}$ of sample $16 \mathrm{~S}$ rRNA gene, followed by addition

10 of $1 \mu \mathrm{L}$ (final concentration of $0.5 \mu \mathrm{M}$ ) of forward and reverse primers along with $2 \mu \mathrm{L}$ of SYBR

11 Green I Master mix, and PCR-grade sterile water to a final volume of $10 \mu \mathrm{L}$. A negative control

12 without the corresponding template 16S rRNA gene was included in each real-time PCR reaction

13 for each primer pair. Amplification of the target 16S rRNA gene used the following conditions:

14 initial $10 \mathrm{~min}$ incubation at $95^{\circ} \mathrm{C}$ for Taq polymerase activation; 30 cycles of denaturation at

$1595^{\circ} \mathrm{C}$ for $10 \mathrm{~s}$, annealing at $56^{\circ} \mathrm{C}\left(\right.$ B. coagulans) or $68^{\circ} \mathrm{C}$ (total bacterial) for $10 \mathrm{~s}$, and extension

16 at $72^{\circ} \mathrm{C}$ for $30 \mathrm{~s}$. The transition rate was $20^{\circ} \mathrm{C} / \mathrm{s}$ for all segments during cycling. Cycle threshold

17 (Ct) was determined by fit point method using LightCycler software (version 3.5, Roche).

18 Standard 16S rRNA gene concentrations were measured using a spectrophotometer (NanoDrop 
1 ND-1000, Wilmington, DE, USA). Each 16S rRNA gene concentration was determined from the

$2 C t$ obtained from regression equations of the external standards.

4 3. Results

\subsection{Fermentation performances}

6 Time courses for the continuous operation are shown in Figure 1. Other SCOD indicates SCOD

7 excluding organic acids, and it was calculated by the difference between SCOD and sum of

8 organic acids measured. TCOD and SCOD were around 140 and 90 gCOD/L, respectively.

9 Particle material and total organic acid concentrations were almost constant during this increased to around $10 \mathrm{gCOD} / \mathrm{L}$ in Run 3, which showed that solubilization was not affected but

12 acidification was delayed and SCOD with larger molecular size remained under low SRT

13 condition. Biogas produced from acid fermenter was mainly composed of $\mathrm{CO}_{2}$ and $\mathrm{H}_{2}$, and

14 methane was not detected during the operation. Acetate, propionate and valerate were almost

15 less than $5 \mathrm{gCOD} / \mathrm{L}$, and butyrate and lactate were the predominant products. Skiadas et al. [28]

16 proposed a model which shows that glucose is converted into lactate or unknown intermediate

17 product, and then they are converted into propionate and acetate, as lactate is a key intermediate

18 of glucose fermentation, especially under high loading condition. In the present study, the HRT 
1 was set at $3.5 \mathrm{~d}$, and high loading condition was maintained. Then, acidification did not reach to

2 propionate and acetate, which would be the substrate of methanogenesis. At the beginning of

3 Run 2, product composition changed a lot, but products at the end of Run 2 and at the beginning

4 of Run 3 were similar. This meant that SRT $10.5 \mathrm{~d}$ in Run 1 might be the critical value to decide

5 the product difference from SRT $7 \mathrm{~d}$ in Run 2 and SRT $3.5 \mathrm{~d}$ in Run 3. Figure 2 shows the

6 average organic acids and hydrogen production in Run 1-3. Organic acids composition,

7 especially butyrate and lactate, changed greatly during the experiment. Butyrate fermentation

8 occurred under the longer SRT condition in Run 1. When SRT was set at shorter in Run 3,

9 lactate production increased, and butyrate and hydrogen production decreased. Noike et al. [29]

10 reported that lactate producing bacteria and hydrogen producing bacteria were competitive for

11 substrate and their products showed reverse relationship. This corresponds with the present

12 study in that lactate production increased and hydrogen production decreased simultaneously.

13 SRT was the important parameters to control organic acids production and bio-hydrogen

14 production in acid fermentation.

$15 \quad 3.2$ Microbial composition

16 A summary of each microbial composition analysis is shown in Table 3. Most OTUs were

17 Firmicutes, and just a few OTUs were Actinobacteria, Bacteroidetes, Proteobacteria and

18 Thermotogae. In Run 1, 78\% OTUs were closely related to Clostridium spp. with average 
1 similarity of $97 \%$. In Run 2, about half OTUs were closely related to Bacillus spp., but not

2 related to $B$. coagulans, and the other half OTUs were closely related to Clostridium spp. Then

3 in Run 3, most OTUs were closely related to B. coagulans with average similarity of $99 \%$.

4 OTUs closely related to Lactobacillus spp. with average similarity of $99 \%$ were also detected in

5 Firmicutes, but their occupying ratio was low. From Run 1 through Run 3, microbial

6 composition change from Clostridium spp. to Bacillus spp., especially B. coagulans was

7 observed. In our reactor, Thermoanaerobacterium was detected only in one sample in Run 3,

8 and was not the key microbe for hydrogen production unlike other researches using food wastes.

$9 \quad$ Time course results for lactate and butyrate concentrations, and B. coagulans and

10 Clostridium spp. ratio measured using random cloning are shown in Figure 3. Product shift from

11 butyrate to lactate and microbial composition shift from Clostridium spp. to B. coagulans were

12 simultaneously observed. The relationship between $B$. coagulans ratio measured using random

13 cloning and organic acid concentrations is shown in Figure 4. Clear relationship between $B$.

14 coagulans ratio and lactate concentration was obtained with $\mathrm{R}^{2}=0.7$. Akao et al. [13] reported

15 results of two microbial composition analysis using random cloning in the semi-continuous

16 fermentation of kitchen garbage at $\mathrm{pH} 6$ and $55^{\circ} \mathrm{C}$ under SRT $=\mathrm{HRT}$ operation. B. coagulans

17 ratio was both approximately $80 \%$ and lactate concentration was both approximately $40 \mathrm{gCOD} / \mathrm{L}$.

18 These values also fit this relationship. When lactate concentration increased, butyrate 
1 concentration decreased, and there was no obvious change in the other organic acid

2 concentrations such as acetate and propionate. The relationship between Clostridium spp. ratio

3 measured using random cloning and organic acid concentrations is shown in Figure 5.

4 Irreversible relationship between Clostridium spp. and lactate accumulation was found having

$5 \quad \mathrm{R}^{2}=0.7$, which was opposite to that between $B$. coagulans and lactate.

$6 \quad 3.3$ Applicability of real-time PCR quantification for B. coagulans

7 Time courses for $16 \mathrm{~S}$ rRNA gene concentrations measured using real-time PCR are shown in

8 Figure 6. Total $16 \mathrm{~S}$ rRNA gene concentration was stably maintained at around $10^{12}$ copies/L,

9 and $16 \mathrm{~S}$ rRNA gene concentration of $B$. coagulans varied in the range of $10^{8}-10^{11}$ copies/L.

10 Hidaka et al. [27] reported that the average ratio of $16 \mathrm{~S}$ rRNA gene concentration to mass of $B$.

11 coagulans was $6.47 \times 10^{10}$ copies/gCOD-biomass in the batch experiment of $B$. coagulans using

12 substrate mainly containing glucose. Using this ratio, in Run $3, B$. coagulans concentration was

13 estimated to be approximately $3.2 \mathrm{gCOD}$-biomass /L. It is equivalent to $2.3 \mathrm{gVS}$-biomass $/ \mathrm{L}$,

14 given that bacterial chemical formula is $\mathrm{C}_{5} \mathrm{H}_{7} \mathrm{O}_{2} \mathrm{~N}$.

16 time PCR is shown in Figure 7. Although the ratio measured using random cloning was nine

17 times higher than that measured using real-time PCR, clear relationship was obtained with

$18 \mathrm{R}^{2}=0.9$. 16S rRNA gene extraction from the samples was same, but after that each procedure 
1 was different, and detection efficiency might be different. This clear relationship proved that

2 both methods can detect change in B. coagulans dominance. The relationship between Bacillus

3 spp. ratio measured using random cloning and B. coagulans ratio measured using real-time PCR

4 is also shown in Figure 7. Unclear relationship with $\mathrm{R}^{2}=0.5$ was observed compared to the

5 previous one. This also verified the specificity of the developed primer for quantification of $B$.

6 coagulans. The relationship between $16 \mathrm{~S}$ rRNA gene concentrations for $B$. coagulans measured

7 using real-time PCR and lactate concentrations is shown in Figure 8. Clear relationship between

8 16S rRNA gene concentrations for B. coagulans and lactate concentration was also obtained with

$9 \quad \mathrm{R}^{2}=0.4$. The results of real-time PCR varied logarithmically, and $\mathrm{R}^{2}$ value could be low, but

10 relationship was obvious. Therefore, real-time PCR can be used to monitor change in $B$.

11 coagulans in kitchen garbage fermentation, where complex organic components are included.

\section{4. Discussion}

14 There are many literatures on thermophilic hydrogen fermentation from carbohydrate. Typical

15 proposed optimum conditions for thermophilic hydrogen fermentation from kitchen garbage or

16 other carbohydrate-rich organic wastes are reported to be around $\mathrm{pH} 5-6[6,7,9,30-33]$.

17 Failure of hydrogen fermentation by lactate production was explained by high loading rate [8, 30,

18 34, 35]. During our continuous experiment, the substrate, HRT, OLR and particle COD 
1 concentrations were almost constant, but SRT was different. In Run 1, where hydrogen

2 production was the highest, SRT was three times higher than HRT. This was possibly helpful to

3 maintain Clostridium spp. and hydrogen production.

$4 \quad$ Akao et al. [13] proposed the condition of $\mathrm{pH} 5-6$ and $55^{\circ} \mathrm{C}$ for semi-continuous lactate

5 fermentation by $B$. coagulans. B. coagulans is included in kitchen garbage, and seeding sludge

6 is not required [14]. Lee et al. [36] reported that lactate and no hydrogen were produced at $\mathrm{pH}$

$7 \quad 5.5$ and hydrogen was produced at $\mathrm{pH} 6$ or over in fermentation of vegetable kitchen wastes

8 under a thermophilic condition with seed sludge from kitchen-waste compost. In practical

9 thermophilic hydrogen fermentation, there must be a risk of failure in hydrogen production by

10 indigenous B. coagulans. Noike et al. [29] reported the consumption of reducing powers to be

11 used for hydrogen gas generation by lactate bacteria of Lactobacillus on mesophilic hydrogen

12 fermentation by Clostridium, and suggested heat treatment for reduction of hydrogen production

13 inhibition. Some other pre-treatment methods including heat, acid and base were proposed for

14 mesophilic hydrogen fermentation of food waste without inoculum addition to kill $\mathrm{H}_{2}$-consuming

15 microorganisms [37]. However, both most Clostridium spp. and B. coagulans are spore-forming,

16 and pre-treatment could not be effective to prevent proliferation of B. coagulans in thermophilic

17 hydrogen production. Antibiotics produced during lactate fermentation might inhibit hydrogen

18 fermentation [38]. B. coagulans produces antibiotics [39, 40], and this characteristic possibly 
1 made the dominance of $B$. coagulans. The growth rate of $B$. coagulans considering the

2 inhibition by a lactate concentration of $25 \mathrm{gCOD} / \mathrm{L}$, like in Run 1 , is estimated to be $0.26(1 / \mathrm{h})$

3 [27]. Collet et al. [41] reported continuous thermophilic hydrogen production by Clostridium

4 thermolacticum under dilution rate of $0.0013-0.19(1 / \mathrm{h})$, and it could be maintained under higher

5 dilution rate. O-Thong et al. [42] reported that Thermoanaerobacterium thermosaccharolyticum

6 PSU-2 in Clostridia had maximum specific growth rate of $0.31(1 / \mathrm{h})$ in thermophilic hydrogen

7 production. Therefore, HRT $3.5 \mathrm{~d}$ was sufficient to retain Clostridium spp. and

8 Thermoanaerobacterium spp. in the reactor, if there were no adverse effects by such as $\mathrm{pH}$, and

9 substrate and product concentrations. Low dominance of Clostridium spp. in Run 3 and low

10 dominance of Thermoanaerobacterium spp. in Runs 1-3 could be due to inhibition of antibiotics

11 produced by $B$. coagulans. Chu et al. [43] recirculated mesophilic methane fermenting sludge

12 for continuous thermophilic hydrogen fermentation at $\mathrm{pH} 5.5$ from food waste. Lee et al. [44]

13 recirculated thermophilic methane fermenting sludge for continuous thermophilic hydrogen

14 fermentation at $\mathrm{pH}$ 5.0-5.7 from food waste. Luo et al. [33] showed that pre-treatment of

15 anaerobic sludge is unnecessary for practical thermophilic hydrogen fermentation from cassava

16 stillage with seed sludge from a full-scale mesophilic upflow anaerobic sludge blanket reactor.

17 In these researches, the substrates could include B. coagulans, but continuous hydrogen

18 production was maintained successfully. Returning or seeding sludge which include bacteria 
1 other than B. coagulans might be the key operation to prevent growth of B. coagulans. In Run 1,

2 high SRT was helpful to retain sufficient Clostridium spp. compared to B. coagulans included in

3 the substrate. Operation of higher SRT than HRT could lead to such an effect as sludge return,

4 and this possibly resulted in maintaining sufficient Clostridium spp. Operational conditions such

5 as OLR, $\mathrm{pH}$, temperature, HRT, SRT and sludge return are essential parameters to decide

6 microbial composition, which affects fermentation products.

Importance of microbial composition monitoring in hydrogen and acid fermentation was

8 presented, and applicability of real-time PCR quantification was proved. Real-time PCR can be

9 applied easier in terms of cost and time than random cloning. Wang et al. [20] reported that 16S

rRNA genes did not exhibit any positive relationship with hydrogen production, and hydrogen

11 production was lineally proportional to the level of functional gene (hydA) expression in the

12 batch experiments. However, our semi-continuous experiment proved the applicability of $16 \mathrm{~S}$ rRNA gene quantification for monitoring bacterial community changes in dark fermentation. In

14 batch cultivation, growth dynamics could be different in each growth phase, such as lag phase

15 and logarithmic phase [45]. In stably operated continuous operation, this effect is minimized, and real-time PCR quantification of $16 \mathrm{~S}$ rRNA can be applied to evaluate microbial composition.

17 Real-time PCR quantification methods would be useful for developing a new monitoring tool in

18 dark fermentative biohydrogen, especially with complex substrates, where many kinds of 
1 bacteria compete with each other in the same reactor.

\section{5. Conclusions}

4 In our continuous fermentation using kitchen garbage, butyrate and hydrogen fermentation

5 occurred under the longer SRT condition, and when SRT was set at shorter, lactate production

6 increased, and butyrate and hydrogen production decreased. Simultaneously, microbial

$7 \quad$ composition shift from Clostridium spp. to Bacillus spp., especially B. coagulans was observed

8 and clear relationship between $B$. coagulans ratio and lactate concentration was obtained.

9 Returning or seeding sludge which include bacteria other than B. coagulans might be the key

10 operation to prevent growth of B. coagulans. Applicability of real-time PCR quantification to

11 monitor change in B. coagulans in kitchen garbage fermentation was verified. Real-time PCR

12 quantification methods would be useful for developing a new monitoring tool for acid

13 fermentation, especially with complex substrates, where many kinds of bacteria compete with

14 each other in the same reactor.

15

16

\section{ACKNOWLEDGEMENTS}

18 This work was supported by CREST of Japan Science and Technology Agency, KAKENHI 
1 (15760408), and Ministry of the Environment, Japan (K2125; K22071). In addition, one of the

2 authors (T. Hidaka) would like to acknowledge "Excellent Young Researcher Overseas Visit

3 Program" of Japan Society for the Promotion of Science.

\section{REFERENCES}

6 [1] Park Y, Hong F, Cheon J, Hidaka T, Tsuno H. Comparison of thermophilic anaerobic

$7 \quad$ digestion characteristics between single-phase and two-phase systems for kitchen garbage treatment. J.Biosci.Bioeng. 2008;1:48-54.

9 [2] Lee M, Hidaka T, Hagiwara W, Tsuno H. Comparative performance and microbial diversity 10 of hyperthermophilic and thermophilic co-digestion of kitchen garbage and excess sludge.

$11 \quad$ Bioresour Technol 2009;2:578-85.

12 [3] Lee M, Hidaka T, Tsuno H. Two-phased hyperthermophilic anaerobic co-digestion of waste 13 activated sludge with kitchen garbage. Journal of Bioscience and Bioengineering 2009;5:40813.

[4] Wang J, Wan W. Factors influencing fermentative hydrogen production: A review. Int J $16 \quad$ Hydrogen Energy 2009;2:799-811.

17 [5] Hallenbeck PC. Fundamentals of the fermentative production of hydrogen. Water Sci $18 \quad$ Technol 2005;1-2:21-9.

19 [6] Akutsu Y, Li Y, Tandukar M, Kubota K, Harada H. Effects of seed sludge on fermentative characteristics and microbial community structures in thermophilic hydrogen fermentation of starch. Int J Hydrogen Energy 2008;22:6541-8. 
1 [7] Shin H, Youn J, Kim S. Hydrogen production from food waste in anaerobic mesophilic and

$2 \quad$ thermophilic acidogenesis. Int J Hydrogen Energy 2004;13:1355-63.

3 [8] Ueno $\mathrm{Y}$, Haruta S, Ishii M, Igarashi Y. Changes in product formation and bacterial 4 community by dilution rate on carbohydrate fermentation by methanogenic microflora in $5 \quad$ continuous flow stirred tank reactor. Appl Microbiol Biotechnol 2001;1-2:65-73.

[9] Ueno Y, Sasaki D, Fukui H, Haruta S, Ishii M, Igarashi Y. Changes in bacterial community during fermentative hydrogen and acid production from organic waste by thermophilic anaerobic microflora. J Appl Microbiol 2006;2:331-43.

[10] Rosenberg M, Rebros M, Kristofikova L, Malatova K. High temperature lactic acid production by Bacillus coagulans immobilized in LentiKats. Biotechnol Lett 2005;2324:1943-7.

[11] Michelson T, Kask K, Jõgi E, Talpsep E, Suitso I, Nurk A. 1(+)-Lactic acid producer Bacillus coagulans SIM-7 DSM 14043 and its comparison with Lactobacillus delbrueckii ssp. lactis DSM 20073. Enzyme and Microbial Technology 2006;4:861-7.

[12] Sakai K, Ezaki Y. Open L-lactic acid fermentation of food refuse using thermophilic Bacillus coagulans and fluorescence in situ hybridization analysis of microflora. Journal of Bioscience and Bioengineering 2006;6:457-63.

[13] Akao S, Tsuno H, Cheon J. Semi-continuous L-lactate fermentation of garbage without sterile condition and analysis of the microbial structure. Water Res 2007;8:1774-80.

[14] Akao S, Tsuno H, Horie T, Mori S. Effects of $\mathrm{pH}$ and temperature on products and bacterial community in L-lactate batch fermentation of garbage under unsterile condition. Water Res 2007;12:2636-42. 
1 [15] Cheon J, Hidaka T, Mori S, Koshikawa H, Tsuno H. Applicability of random cloning

2 method to analyze microbial community in full-scale anaerobic digesters. J.Biosci.Bioeng.

$3 \quad 2008 ; 2: 134-40$.

4 [16] Yu Y, Kim J, Hwang S. Use of real-time PCR for group-specific quantification of $5 \quad$ aceticlastic methanogens in anaerobic processes: Population dynamics and community $6 \quad$ structures. Biotechnol Bioeng 2006;3:424-33.

7 [17] Kobayashi T, Yasuda D, Li Y, Kubota K, Harada H, Yu H. Characterization of start-up 8 performance and archaeal community shifts during anaerobic self-degradation of waste$9 \quad$ activated sludge. Bioresour Technol 2009;21:4981-8.

10 [18] Li C, Zhang T, Fang HH. Use of TaqMan gene probe for real-time monitoring of 11 acidophilic hydrogen-producing bacteria. Biotechnol Lett 2007;11:1753-7.

[19] Wang MY, Olson BH, Chang JS. Relationship among growth parameters for Clostridium butyricum, hydA gene expression, and biohydrogen production in a sucrose-supplemented batch reactor. Appl Microbiol Biotechnol 2008;3:525-32.

[20] Wang M, Tsai Y, Olson BH, Chang J. Monitoring dark hydrogen fermentation performance of indigenous Clostridium butyricum by hydrogenase gene expression using RT-PCR and qPCR. Int J Hydrogen Energy 2008;18:4730-8.

[21] Tanigawa N, Takemoto T, Ohki H, Kawasaki T. Detailed component of garbage. J Jpn Waste Manage Assoc 1997:116-9.

20 [22] DuBois M, Gilles KA, Hamilton JK, Rebers PA, Smith F. Colorimetric Method for 21 Determination of Sugars and Related Substances. Anal Chem (Wash ) 1956;3:350-6.

22 [23] Lowry OH, Rosebrough NJ, Farr AL, Randall RJ. Protein measurement with the Folin 23 phenol reagent. J Biol Chem 1951;1:265-75. 
[24] APHA, AWWA, WEF. Standard Methods for the Examination of Water and Wastewater, 19th ed. Washington, DC: American Public Health Association Publications; 1995.

[25] Lane DJ. 16S/23S rRNA sequencing. In Nucleic acid tequniques in bacterial systematics, Stackebrandt, E. and Goodfellow, M. (ed.), Chichester, Wiley 1991:115-75.

[26] Altschul SF, Gish W, Miller W, Myers EW, Lipman DJ. Basic local alignment search tool. J Mol Biol 1990;3:403-10.

[27] Hidaka T, Horie T, Akao S, Tsuno H. Kinetic model of thermophilic l-lactate fermentation by Bacillus coagulans combined with real-time PCR quantification. Water Res 2010;8:255462.

[28] Skiadas IV, Gavala HN, Lyberatos G. Modelling of the periodic anaerobic baffled reactor (PABR) based on the retaining factor concept. Water Res 2000;15:3725-36.

[29] Noike T, Takabatake H, Mizuno O, Ohba M. Inhibition of hydrogen fermentation of organic wastes by lactic acid bacteria. Int J Hydrogen Energy 2002;11-12:1367-71.

[30] Akutsu Y, Li Y, Harada H, Yu H. Effects of temperature and substrate concentration on biological hydrogen production from starch. Int J Hydrogen Energy 2009;6:2558-66.

[31] Shin HS, Youn JH. Conversion of food waste into hydrogen by thermophilic acidogenesis. Biodegradation 2005;1:33-44.

[32] Ueno Y, Fukui H, Goto M. Operation of a Two-Stage Fermentation Process Producing Hydrogen and Methane from Organic Waste. Environ Sci Technol 2007;4:1413-9.

[33] Luo G, Xie L, Zou Z, Wang W, Zhou Q. Evaluation of pretreatment methods on mixed inoculum for both batch and continuous thermophilic biohydrogen production from cassava stillage. Bioresour Technol 2010;3:959-64.

[34] Temudo MF, Kleerebezem R, van Loosdrecht M. Influence of the $\mathrm{pH}$ on (open) mixed culture fermentation of glucose: A chemostat study. Biotechnol Bioeng 2007; 98(1): 69-79. 
1 [35] Liu D, Zeng RJ, Angelidaki I. Effects of $\mathrm{pH}$ and hydraulic retention time on hydrogen

2 production versus methanogenesis during anaerobic fermentation of organic household solid

3 waste under extreme-thermophilic temperature (70 degrees C). Biotechnol Bioeng 2008;

$4 \quad 100(6): 1108-1114$.

5 [36] Lee Z, Li S, Lin J, Wang Y, Kuo P, Cheng S. Effect of $\mathrm{pH}$ in fermentation of vegetable

6 kitchen wastes on hydrogen production under a thermophilic condition. Int J Hydrogen

$7 \quad$ Energy 2008;19:5234-41.

8 [37] Kim D, Kim S, Shin H. Hydrogen fermentation of food waste without inoculum addition.

$9 \quad$ Enzyme Microb Technol 2009;3:181-7.

10 [38] Noike T, Ko IB, Yokoyama S, Kohno Y, Li YY. Continuous hydrogen production from 11 organic waste. Water Sci Technol 2005;1-2:145-51.

[39] Hyronimus B, Le Marrec C, Urdaci MC. Coagulin, a bacteriocin-like inhibitory substance produced by Bacillus coagulans I4. J Appl Microbiol 1998;1:42-50.

[40] Adami A, Cavazzoni V. Occurrence of selected bacterial groups in the faeces of piglets fed with Bacillus coagulans as probiotic. J Basic Microbiol 1999;1:3-9.

[41] Collet C, Adler N, Schwitzguébel J, Péringer P. Hydrogen production by Clostridium thermolacticum during continuous fermentation of lactose. Int $\mathrm{J}$ Hydrogen Energy 2004;14:1479-85.

[42] O-Thong S, Prasertsan P, Karakashev D, Angelidaki I. Thermophilic fermentative hydrogen production by the newly isolated Thermoanaerobacterium thermosaccharolyticum PSU-2. Int J Hydrogen Energy 2008;4:1204-14.

[43] Chu C, Li Y, Xu K, Ebie Y, Inamori Y, Kong H. A pH- and temperature-phased two-stage process for hydrogen and methane production from food waste. Int J Hydrogen Energy 2008;18:4739-46. 
1 [44] Lee D, Ebie Y, Xu K, Li Y, Inamori Y. Continuous H2 and CH4 production from high-solid

2 food waste in the two-stage thermophilic fermentation process with the recirculation of

$3 \quad$ digester sludge. Bioresour Technol 2010;1, Supplement 1:S42-7.

4 [45] Ha JH, Hidaka T, Tsuno H. Quantification of toxic microcystis and evaluation of its

5 dominance ratio in blooms using real-time PCR. Environmental Science and Technology

$6 \quad 2009 ; 43(3): 812-818$.

7 
1 Table 1 Experimental condition

\begin{tabular}{ccccc}
\hline & & Run 1 & Run 2 & Run 3 \\
\hline Period & (d) & $0-25$ & $26-110$ & $111-300$ \\
\hline HRT & (d) & 3.5 & 3.5 & 3.5 \\
\hline SRT & (d) & 10.5 & 7 & 3.5 \\
\hline OLR & (gCODcr/(L-reactor $\cdot d))$ & 43 & 43 & 43 \\
\hline pH & $(-)$ & 6 & 6 & 6 \\
\hline
\end{tabular}

2

3 
1 Table 2 Characteristics of raw kitchen garbage

\begin{tabular}{lcc}
\hline & Total & Soluble \\
\hline TS $(\mathrm{g} / \mathrm{L})$ & 189 & - \\
\hline $\mathrm{SS}(\mathrm{g} / \mathrm{L})$ & 120 & - \\
\hline $\mathrm{VS}(\mathrm{g} / \mathrm{L})$ & 179 & - \\
\hline $\mathrm{COD}(\mathrm{g} / \mathrm{L})$ & 292 & 104 \\
\hline Carbohydrate (g/L as glucose) & 145 & 79 \\
\hline Protein (g/L as albumin) & 55 & 15 \\
\hline T-N (mgN/L) & 4.8 & 1.7 \\
\hline $\mathrm{pH}(-)$ & 4.8 & - \\
\hline
\end{tabular}

2 
1 Table 3 Summary of microbial diversity analysis

\begin{tabular}{|c|c|c|c|c|c|c|c|c|c|c|c|c|}
\hline \multirow{3}{*}{ Phylum } & \multirow{3}{*}{ Order } & \multirow{3}{*}{ Genus } & \multirow{3}{*}{$\begin{array}{l}\text { Average } \\
\text { similarity }\end{array}$} & \multicolumn{9}{|c|}{ day } \\
\hline & & & & \multirow{2}{*}{\begin{tabular}{|l} 
Run 1 \\
25 \\
\end{tabular}} & \multicolumn{4}{|c|}{ Run 2} & \multicolumn{4}{|c|}{ Run 3} \\
\hline & & & & & 45 & 67 & 82 & 103 & 124 & 153 & 180 & 219 \\
\hline \multicolumn{4}{|c|}{ Number of clone analyzed } & 91 & 94 & 93 & 93 & 92 & 104 & 95 & 93 & 94 \\
\hline \multicolumn{3}{|c|}{ Actinobacteria } & & & & & & 1 & & & 1 & \\
\hline \multicolumn{3}{|l|}{ Bacteroidetes } & & & & & & & & & 1 & \\
\hline \multirow[t]{8}{*}{ Firmicutes } & \multirow[t]{3}{*}{ Bacillales } & Bacillus coagulans & $99 \%$ & 3 & & & 1 & & 93 & 89 & 88 & 69 \\
\hline & & Bacillus spp. & $99 \%$ & 10 & 50 & & 34 & 82 & & 1 & 3 & 9 \\
\hline & & [others] & & & & & 3 & & & & & 1 \\
\hline & \multirow[t]{3}{*}{ Clostridia } & Clostridium spp. & $97 \%$ & 78 & 37 & 91 & 42 & 12 & & & 1 & 19 \\
\hline & & Thermoanaerobacterium spp. & $100 \%$ & & & & & & & & 1 & \\
\hline & & [others] & & 1 & 4 & 2 & 13 & 2 & & & & \\
\hline & \multirow[t]{2}{*}{ Lactobacillales } & Lactobacillus spp. & $99 \%$ & 4 & 4 & 4 & & & 1 & 7 & & 1 \\
\hline & & [others] & & & & 1 & 2 & & & 2 & 2 & 1 \\
\hline \multicolumn{3}{|c|}{ Proteobacteria } & & & 1 & & 2 & 3 & 1 & & 2 & \\
\hline \multicolumn{3}{|l|}{ Thermotogae } & & & & & & & 4 & & & \\
\hline \multicolumn{3}{|l|}{ Uncertain } & & 3 & 3 & 1 & 2 & & 1 & & & \\
\hline
\end{tabular}

3 detected ratios expressed as (\%) 
1 Figure 1 Time course results for the continuous operation. (a) TCOD, SCOD, total 2 organic acid, butyrate and lactate; (b) acetate, propionate, valerate and other organic 3 acids.

4

$5 \quad$ Figure 2 Average organic acid and hydrogen production (average \pm SD).

6

7 Figure 3 Time course results for lactate and butyrate concentrations, and B. coagulans 8 and Clostridium spp. ratio measured using random cloning.

9

Figure 4 Relationship between $B$. coagulans ratio measured using random cloning and organic acid concentrations.

Figure 5 Relationships between Clostridium spp. ratio measured using random cloning and organic acid concentrations.

Figure 6 Time course results for 16S rRNA gene concentrations.

Figure 7 Relationship between B. coagulans or Bacillus spp. ratio measured using random cloning and B. coagulans ratio measured using real-time PCR.

Figure 8 Relationship between 16S rRNA gene concentrations for B. coagulans measured using real-time PCR and lactate concentrations. 
$1 \quad$ Figure 1
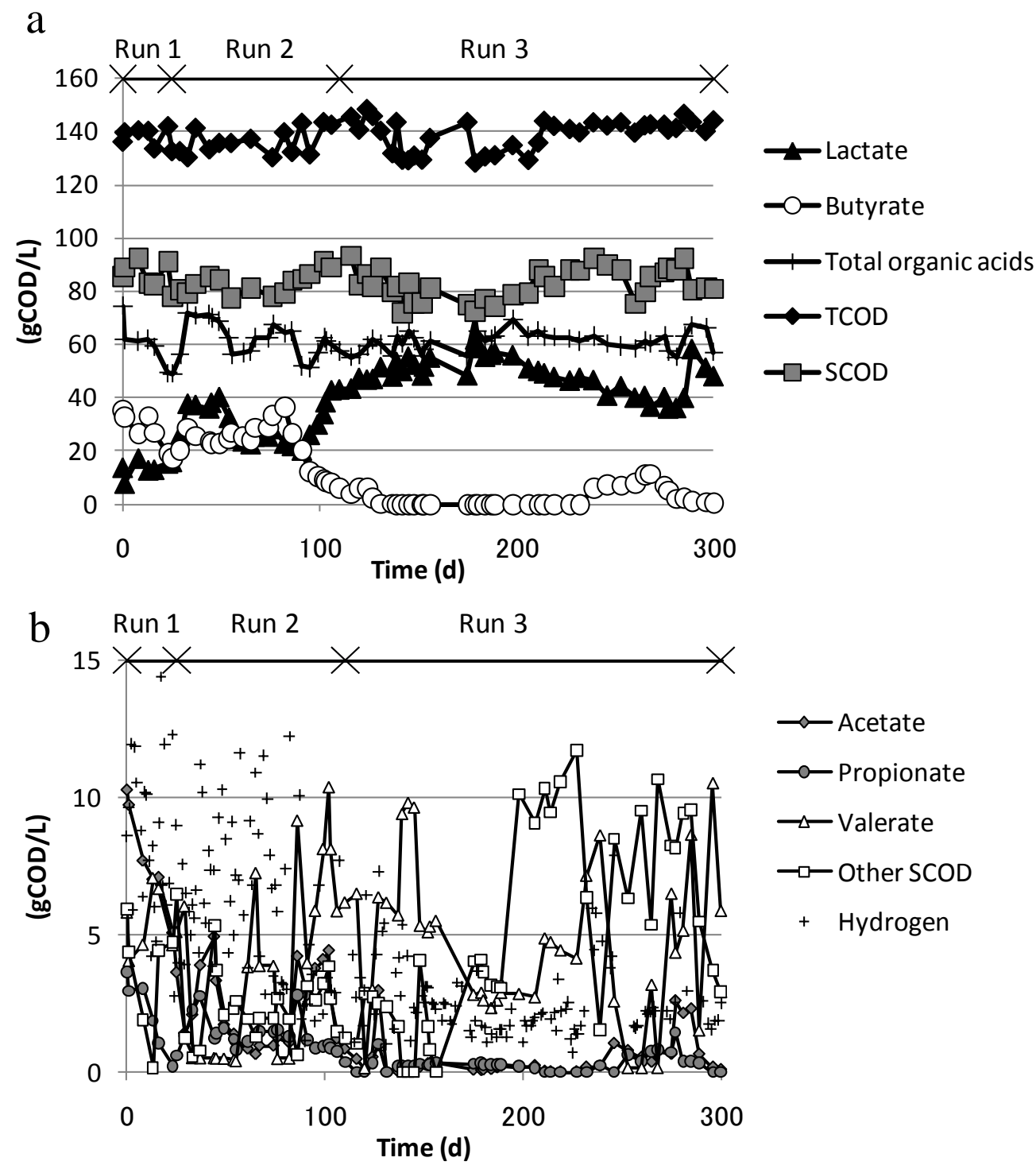
$1 \quad$ Figure 2

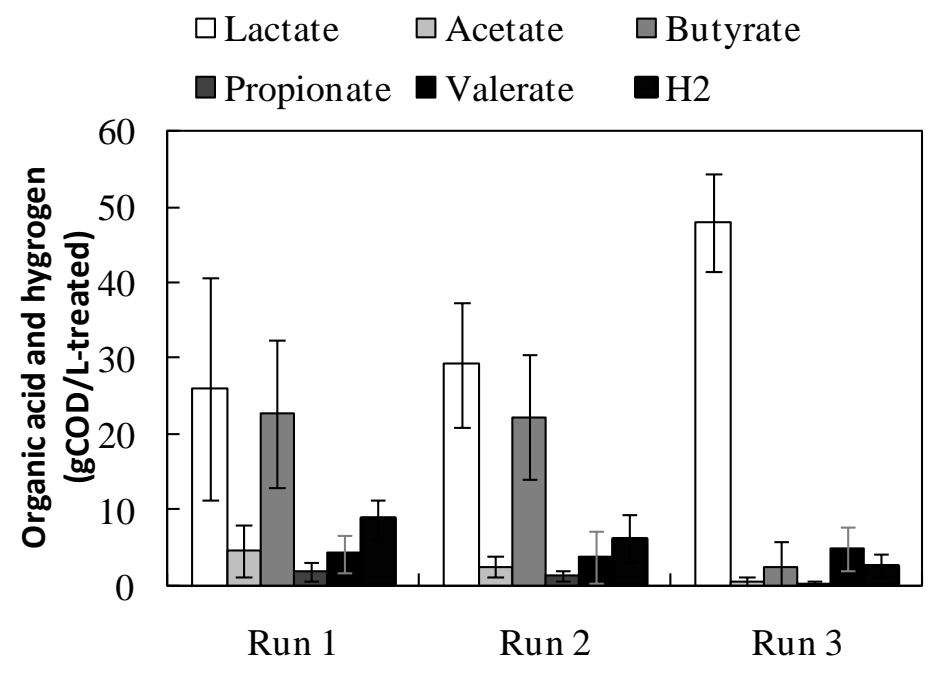

3 
$1 \quad$ Figure 3

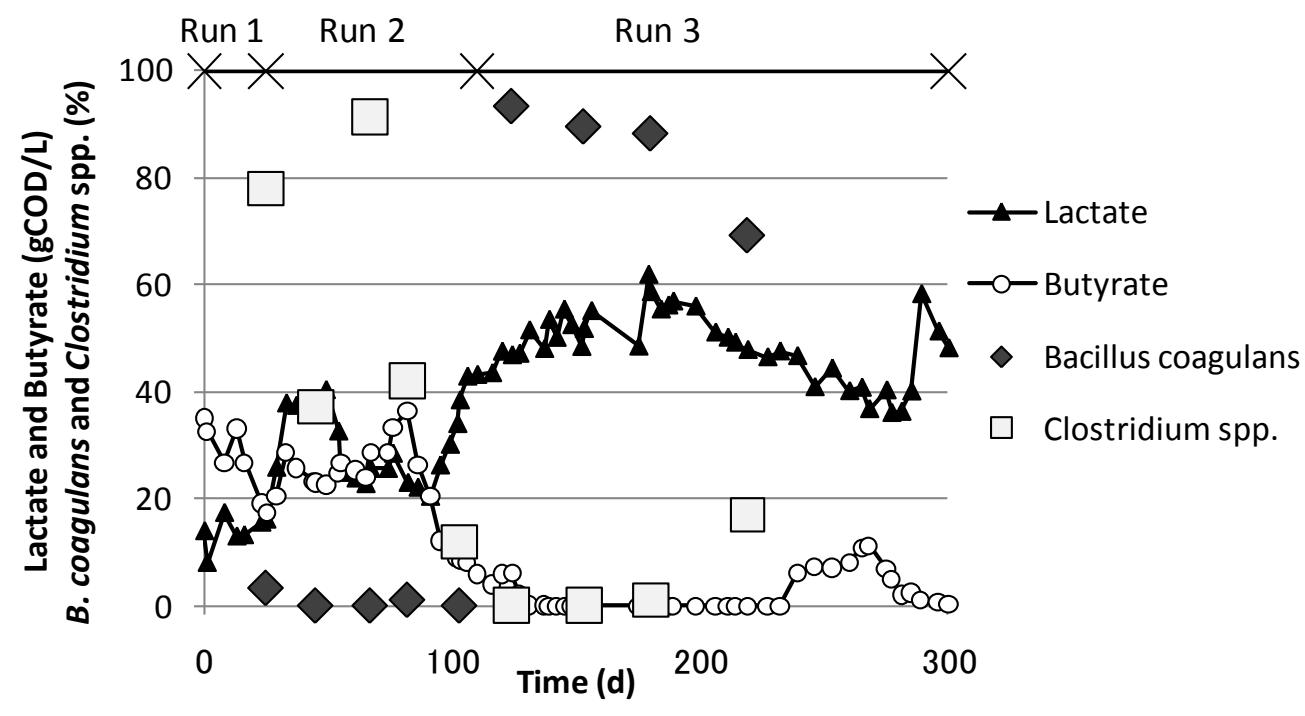

3 
$1 \quad$ Figure 4

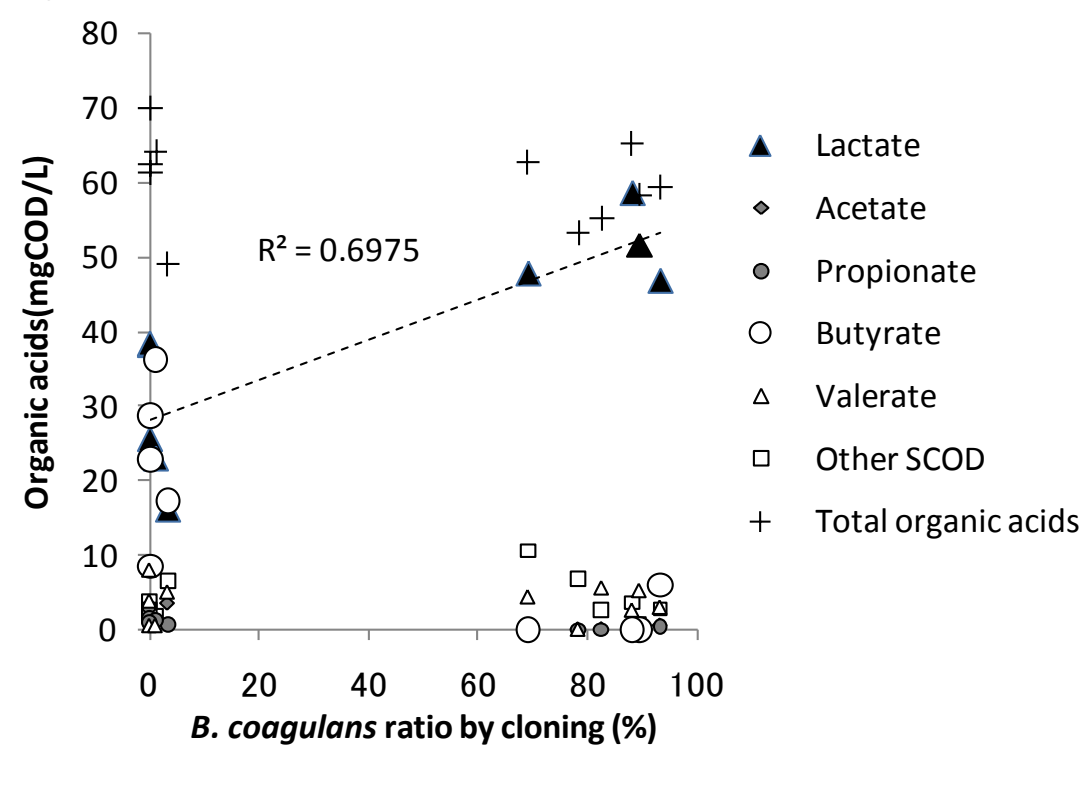

3 
1 Figure 5

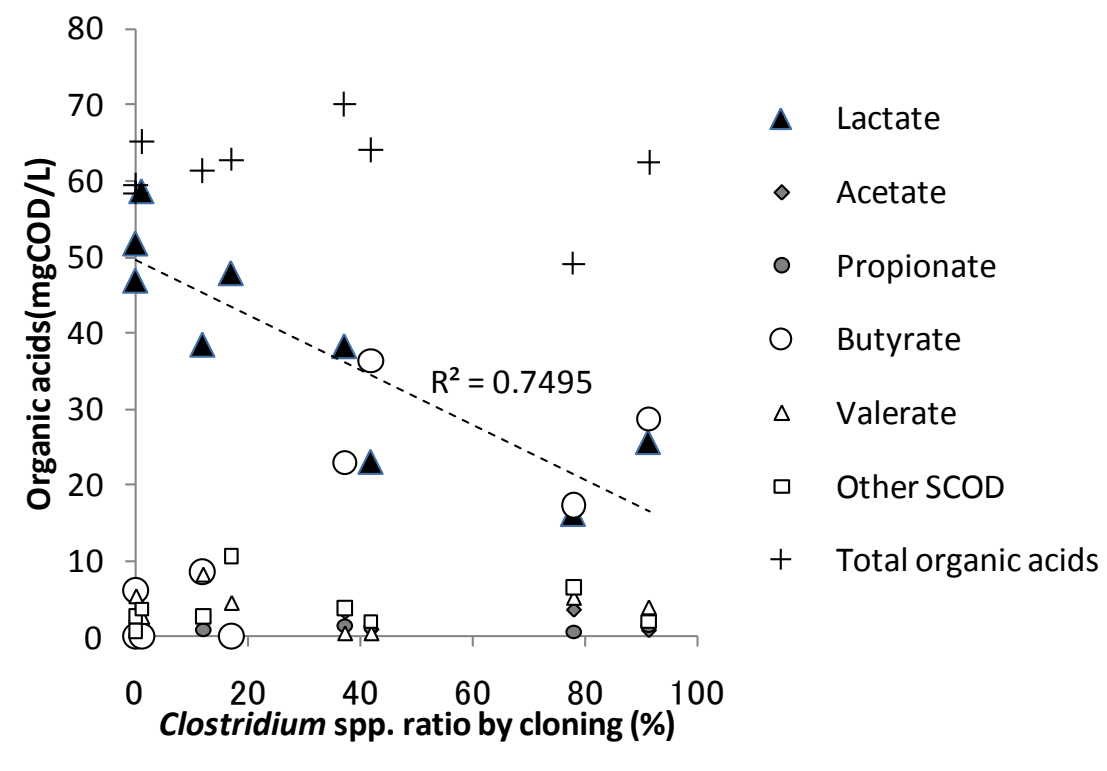

3 
$1 \quad$ Figure 6

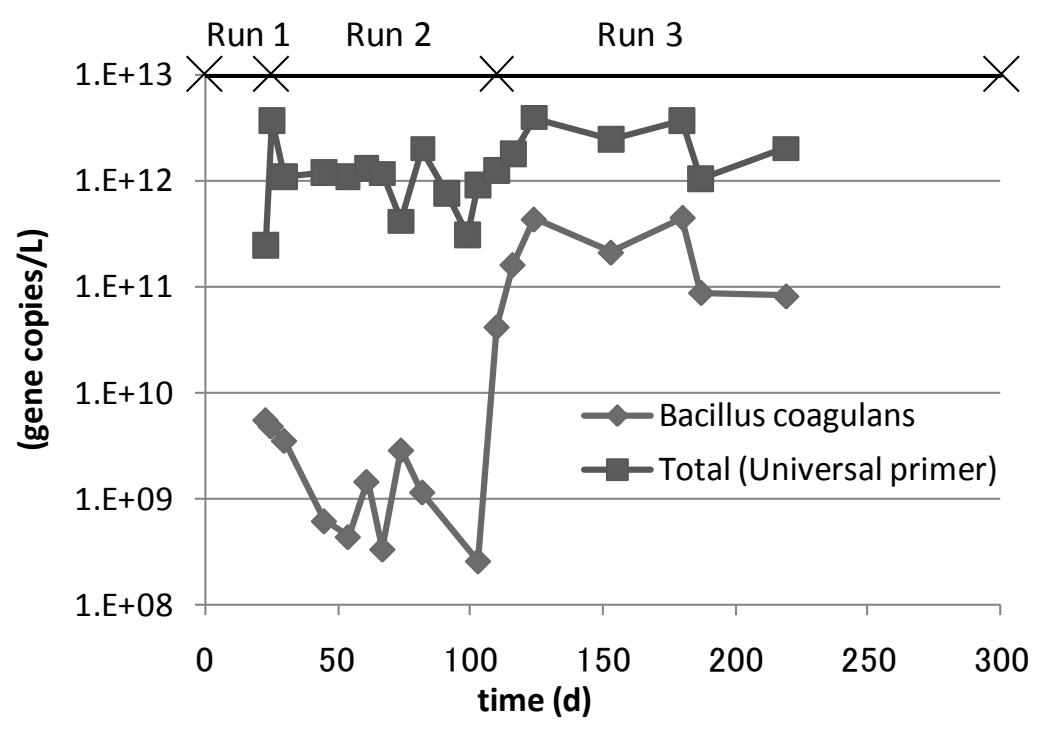

3 
$1 \quad$ Figure 7

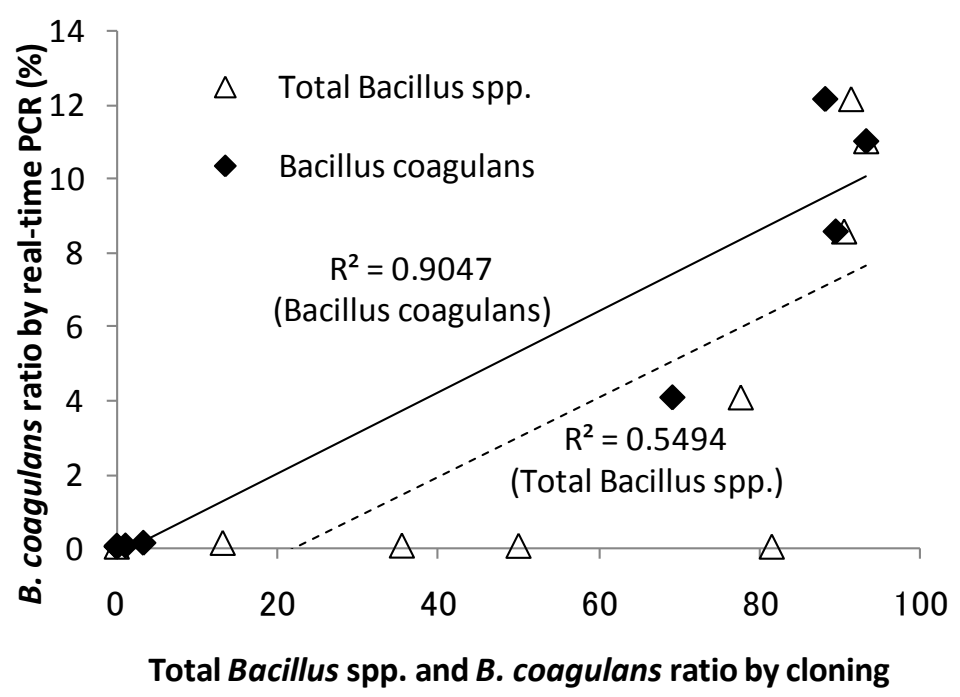


$1 \quad$ Figure 8

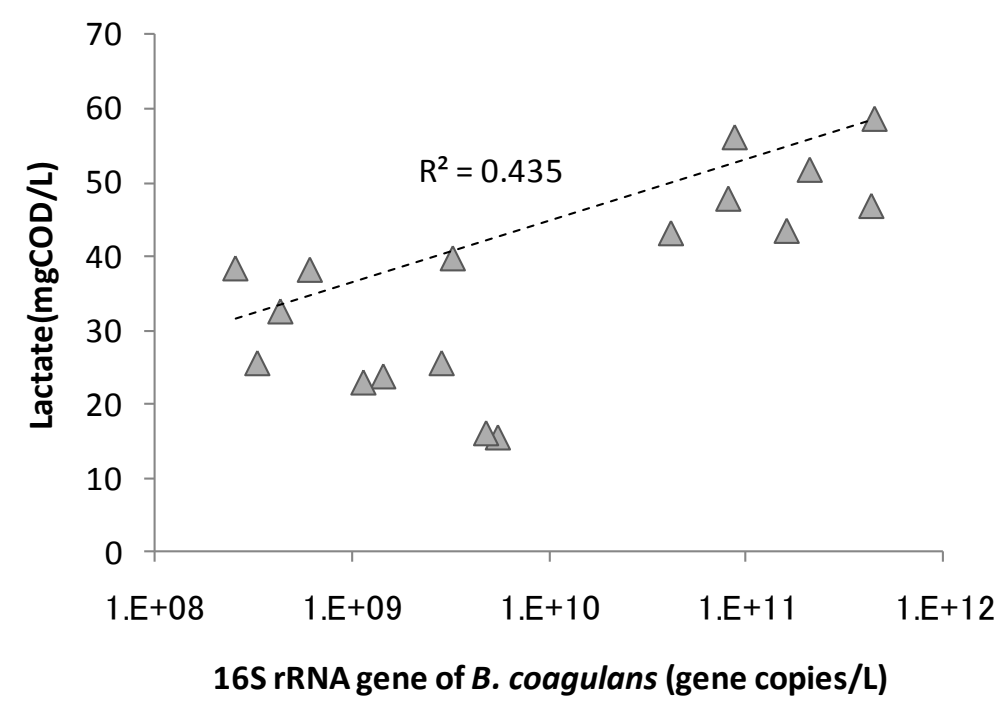

2 